\title{
Jak wychowywać do życia w rodzinie?*
}

Przedstawiona poniżej refleksja na temat wychowania do życia w rodzinie powstała na bazie trzech źródeł. Pierwszym jest wieloletnia osobista praktyka autora i jego żony, śp. Marioli Wołochowicz ${ }^{1}$, w prowadzeniu dla młodzieży zajęć z przygotowania do życia w rodzinie (dalej PDŻ) w szkołach oraz $\mathrm{w}$ innych miejscach (w tym także w ramach pracy statutowej prowadzonej przez nich Fundacji Misja Służby Rodzinie ${ }^{2}$ ). Po drugie Mariola i Piotr Wołochowiczowie są współautorami publikacji Zanim wybierzesz..., która otrzymała akceptację Ministerstwa Edukacji Narodowej jako książki pomocniczej do PDŻ dla szkoły średniej ${ }^{3}$, oraz skorelowanego z nią Programu do przedmiotu wychowanie do życia $w$ rodzinie 4 . Wreszcie jako rodzice

Tekst stanowi rozszerzoną wersję wystąpienia Jak wychowywać do życia w rodzinie? wygłoszonego podczas konferencji „Rodzina - Wychowanie - Przyszłość” zorganizowanej przez Polskie Stowarzyszenie Familiologiczne 27 lutego 2020 roku na UPJPII w Krakowie.

1 Maria Jolanta Wołochowicz (1961-2016), mgr germanistyki i mgr lic. teologii, autorka i współautorka kilkunastu książek dot. rodziny; strona pamiątkowa: www.mariola.wolochowicz.pl.

2 Fundacja Misja Służby Rodzinie: www.msr.org.pl.

3 M. i W. Grabowscy, A. i M. Niemyscy, M. i P. Wołochowiczowie, Zanim wybierzesz... Przygotowanie do życia w rodzinie. Podstawy wychowania seksualnego, wyd. 2, Warszawa 1999.

$4 \quad$ M. i W. Grabowscy, A. i M. Niemyscy, M. i P. Wołochowiczowie, Zanim wybierzesz... Program do przedmiotu wychowanie do życia w rodzinie, Warszawa 1999. 
trójki dzieci (Magdalena - 83'; Daniel - 86'; Ireneusz - 88’) sami skutecznie je wychowali do życia w rodzinie.

\section{Współczesne realia wychowawcze}

Początek XXI wieku nasilił niepokojące trendy, które pojawiły się już u schyłku drugiego tysiąclecia. Można zauważyć szczególnie trzy zjawiska:

- coraz większa bezradność rodziców co do wychowania w ogóle - tracą oni nadzieję, rezygnują z aktywnego wychowania, przyjmują modernistyczne wzorce ze świata za normę;

- brak świadomego programu wychowawczego - rodzice często uważają, że „grzeczne dziecko” się trafia lub nie;

- kolosalne osłabienie, a właściwie upadek mechanizmu dotychczasowego przekazu wartości (a szczególnie wiary) z pokolenia na pokolenie.

Niestety coraz więcej rodziców daje się wprowadzić w to błędne myślenie, z ich ust padają stwierdzenia: „takie są czasy”, „nic nie można poradzić”, „ach, ta dzisiejsza młodzież”, „kiedyś było inaczej” itp.

W tym kontekście bardzo ważne przesłanie przynosi ogłoszony w roku 2008 przez Benedykta XVI List do diecezji rzymskiej o pilnej potrzebie wychowania. Papież rozpoznaje współczesny kryzys wychowawczy następująco: „W sposób naturalny winą obarcza się w tej sytuacji nowe pokolenia, jak gdyby dzieci, które rodzą się dzisiaj, były inne od tych, które rodziły się w przeszłości. Mówi się ponadto o «rozłamie między pokoleniami», który niewątpliwie istnieje i ma swoje znaczenie, lecz jest on raczej skutkiem niż przyczyną tego, że nie przekazuje się pewników i wartości" ${ }^{5}$. Niezwykle ważne jest wskazanie, że rozłam między pokoleniami to skutek błędów wychowawczych, a nie ich przyczyna.

Wobec tego Benedykt XVI zachęca: „Nie obawiajcie się! Wszystkie te

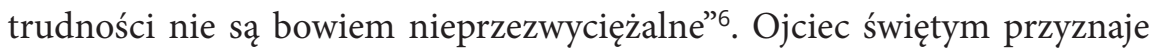
priorytet rzeczywistości duchowej: „Kto wierzy w Jezusa Chrystusa, ma

\footnotetext{
5 Benedykt XVI, List do diecezji rzymskiej o pilnej potrzebie wychowania, (21.01.2008), „L'Osservatore Romano” wyd. pol. (2008) nr 4 (302), s. 4.

$6 \quad$ Benedykt XVI, List do diecezji rzymskiej o pilnej potrzebie wychowania, s. 4.
} 
jeszcze dodatkowy, silniejszy powód, by nie odczuwać lęku: wie bowiem, że Bóg nas nie opuszcza, że Jego miłość dosięga nas tam, gdzie jesteśmy, i takich, jacy jesteśmy, z naszą nędzą i słabościami, by nam ofiarować nową szansę dobra"'. Zadanie wychowania dzieci pochodzi od Boga i to od Niego rodzice mają zapewnioną pomoc.

Niestety współczesna cywilizacja coraz bardziej neguje model zasadniczej odpowiedzialności rodziców za wychowanie. Przyzwala ona na nieobecność ojców, atakuje też klasyczną rolę matki. Kathi Mills pisze w książce Mamusiu, gdzie jesteś? Czyli: o trudnych wyborach wspótczesnej kobiety: „Opinia społeczna w przeważającej większości traktuje dziś macierzyństwo jako dodatkowe zajęcie, które trzeba upchnąć gdzieś między pracą zawodową a osobistymi zainteresowaniami”". Pojawia się zjawisko, które nazwać można wychowaniem społecznym: „Jest to przekonanie, że najlepiej wychowywać dzieci potrafi ktoś inny niż rodzice, najczęściej państwo"9.

Cechą współczesnych rodzin jest też bardzo częste rozpieszczanie dzieci. Albert Wunsch wskazuje niemieckim rodzicom, że nie bez powodu ich dzieci są skupione na sobie: „stojące i lamentujące postacie bez pomysłów, sfrustrowane, asocjalne, bez sił, bez odwagi, bez perspektyw na przyszłośćc ${ }^{10}$. Przyczyną tego jest bowiem pedagogika frajdy, czyli nadmierne staranie się, aby dziecku zawsze było miło, atrakcyjnie i aby wszystko dostawało w formie zabawy. Tymczasem: „Dzieci nie oczekują, że rodzice będą całymi dniami na wszelki możliwy sposób otaczać propozycjami zajęć"11. Wunsch widzi związek pomiędzy takim modelem wychowania młodego pokolenia a jego obecnymi słabościami: gubienie się w wielości wyborów, egoizm, chęć życia bez zobowiązań (nawet w małżeństwie), niemożność podejmowania wiążących decyzji.

\footnotetext{
$7 \quad$ Benedykt XVI, List do diecezji rzymskiej o pilnej potrzebie wychowania, s. 4.

$8 \quad$ K. Mills, Mamusiu, gdzie jesteś? Czyli: o trudnych wyborach współczesnej kobiety, Warszawa 1994, s. 19.

$9 \quad$ K. Mills, Mamusiu, gdzie jesteś?, dz. cyt., s. 38.

10 A. Wunsch, Die Verwöhnungsfalle. Für eine Erziehung zu mehr Eigenverantwortlichkeit, München 2013, s. 23, tłum. M. Wołochowicz.

11 A. Wunsch, Abschied von der Spaßpädagogik. Für einen Kurswechsel in der Erziehung, München 2003, s. 15, tłum. M. Wołochowicz.
} 


\section{Wychowanie do życia w rodzinie}

Realne efekty wychowania do życia w rodzinie będą pochodną dwóch obszarów życia młodego człowieka. Pierwszym jest środowisko, w którym konkretna osoba jest wychowywana. Czynnikami sprzyjającymi rozwojowi młodego człowieka są przede wszystkim: stabilna rodzina, atmosfera pełna miłości, wzajemne głębokie oddanie, właściwy system wartości, czystość obyczajowa i prawość w życiu członków rodziny, poświęcenie ze strony rodziców czasu, sił i środków, aby zatroszczyć się o dzieci. Warunkują one naturalne przekazywanie wartości i stylu życia z pokolenia na pokolenie, zaś pomoc z zewnątrz jest tylko dodatkiem w razie konkretnych potrzeb.

Drugim obszarem jest konkretny przekaz, jaki do młodego człowieka ma trafić. Najważniejsze jego dziedziny to: kształtowanie charakteru, rozmowy na konkretne tematy - dostosowane do wieku i potrzeb dzieci - ukazanie zależności między wyborami a konsekwencjami, budowa systemu wartości, wychowanie w kwestii płciowości i płodności, przekaz wiary.

Jednym z kluczowych celów wychowania jest troska, aby skutecznie kształtować dziecko w sferze aksjologicznej. W modelowym procesie rozwoju człowieka dominująca motywacja jego postępowania zmienia się kolejno według schematu: popędowa - emocjonalna - poznawcza ${ }^{12}$. We wczesnym dzieciństwie dominuje motywacja popędowa - dążenie z całą siłą do tego, by natychmiast zredukować napięcie (mokra pielucha, głód, brak towarzystwa itp.); dzieje się to niezależnie od ograniczeń (małe dziecko nie potrafi tego dążenia odroczyć). Potem stopniowo pojawia się i rozwija motywacja emocjonalna - dążenie do tego, co sprawia przyjemność (smaczne jedzenie, zabawa, nieróbstwo), oraz unikanie tego, co nieprzyjemne (np. sprzątanie). Trzeci etap to motywacja poznawcza, czyli poszukiwanie sensu życia i prawdziwych wartości; człowiek podejmuje aktywność, by rozpoznać znaczenie tego, co jest obiektywnie warte pragnienia ${ }^{13}$.

Na pierwszym i drugim etapie wartości i motywacje podsuwane są człowiekowi z zewnątrz. Dopiero po przejściu tych dwóch faz będzie on w stanie przejść na trzeci stopień i dalej już samodzielnie motywować się prawdziwymi wartościami. Mimo że nadal istnieją w nim zmysłowość i popędowość,

12 B. Zarzycka, Rozwój własny a życie oddane Ewangelii, „Pastores. Kwartalnik Poświęcony Formacji Kapłańskiej” (2010) nr 3 (48), s. 29.

13 Por. B. Zarzycka, Rozwój własny a życie oddane Ewangelii, dz. cyt., s. 29-32. 
nie dominują go one i nie zniewalają (jak na etapie pierwszym). Nie ograniczają go również przeżywane emocje (jak to ma miejsce na etapie drugim). Człowiek jest w stanie skutecznie opierać się pokusom, gdyż trwała wartość jest dla niego ważniejsza od chwilowej korzyści. Dla rodziców, oddanych swemu powołaniu wychowania dziecka ku wartościom, świadomość i rozpoznawanie faz procesu rozwojowego pomaga $w$ skutecznym kształtowaniu dziecka. Młody człowiek, aby w przyszłości móc założyć własną rodzinę, musi być przecież ukształtowany $\mathrm{w}$ tym obszarze.

Wychowanie do życia w rodzinie jest częścią wychowania w ogóle i może przynieść pozytywne rezultaty dopiero w kontekście szeroko pojętego kształtowania młodego pokolenia. Poniższy schemat pokazuje postulowany model przekazu pomiędzy pokoleniami ${ }^{14}$ :

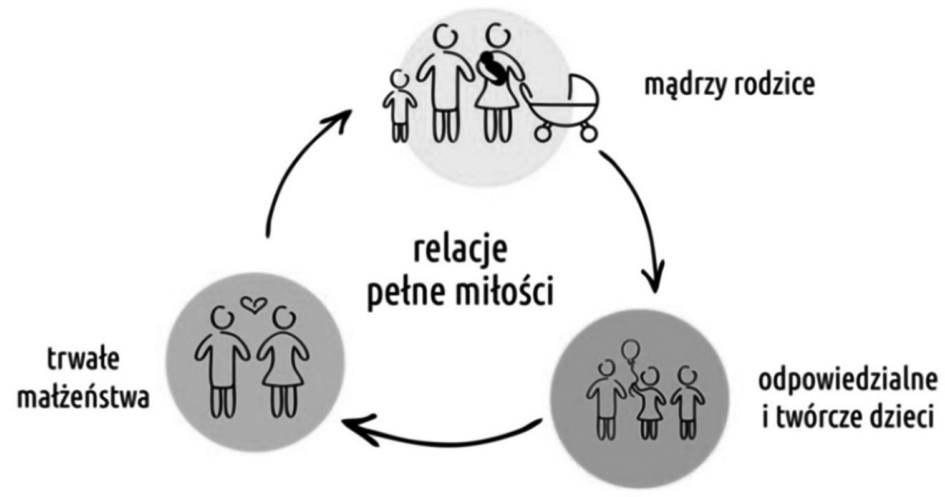

Źródło: Materiały własne Fundacji Misja Służby Rodzinie (2015).

Wychowanie do życia $\mathrm{w}$ rodzinie obejmować będzie przygotowanie młodego człowieka do funkcjonowania w kluczowych sferach, które przedstawione są na schemacie. Aby móc zbudować trwałe małżeństwo, młoda osoba potrzebuje przede wszystkim ukształtowanego systemu wartości, dojrzałości osobowej, mądrości życiowej (w także kwestii wyboru współmałżonka), zrozumienia tego, czym jest prawdziwa miłość, i gotowości do jej realizacji. Kiedy urodzą się dzieci, mądrzy rodzice będą wychowywać je

14 Schemat ten jest owocem wieloletniej pracy Marioli i Piotra Wołochowicz w ramach Misji Służby Rodzinie. Warto jednak dodać, że autorką ujęcia graficznego jest Magdalena Wołochowicz, córka autora, co samo w sobie stanowi przykład na realność przekazu pokoleń $\mathrm{w}$ tej rodzinie. 
w pełnej miłości, zawierającej w sobie także wymagania i dyscyplinę. Dzięki temu dzieci będą odpowiedzialne i twórcze, zdolne potem, by - odpowiednio przygotowane - same zbudować trwałe małżeństwo.

Cały ten proces opiera się na głębokich więziach w rodzinie oraz internalizacji wartości. Podkreśla to Marian Wolicki w artykule Psychologiczne uwarunkowania przekazu wartości w rodzinie: „Przekaz wartości w rodzinie $\mathrm{z}$ rodziców na dzieci jest uwarunkowany procesem internalizacji tych wartości, a $\mathrm{z}$ kolei internalizacja jest zależna od wcześniejszego procesu identyfikacji dziecka z rodzicami”' ${ }^{15}$. Autor wyciąga stąd wniosek, iż to proces identyfikacji jest podstawą do skutecznej internalizacji wartości. Aby jednak był on w ogóle możliwy, konieczne jest wcześniej: „zaistnienie pomiędzy rodzicami a dzieckiem szczerej i głębokiej więzi uczuciowej oraz opartych na niej wzajemnych interakcji” ${ }^{16}$.

\section{Program wychowawczy}

Wobec współczesnych wyzwań potrzeba, aby rodzice wrócili do znanego wcześniejszym pokoleniom tworzenia indywidualnych programów wychowawczych dla dzieci. Powinni oni mieć konkretną wizję tego, jakich ludzi chcą kiedyś zobaczyć w swoich dzieciach. Przykładowo cel taki określa Jill Savage: „Zawód matki jest określony przez cel nadrzędny: wychować dzieci na dojrzałych, wrażliwych, pełnych szacunku i miłości wierzących ludzi”"17. Grunt do tego stworzą obecność rodziców, stały z nimi kontakt, ciepłe relacje i wzajemne zaufanie. Będzie nim także ochrona dziecka przed niewłaściwymi wpływami i kontaktami i jednocześnie promowanie dobrych kontaktów z rówieśnikami pochodzącymi z rodzin reprezentujących podobne wartości i styl życia (w tym także wspólnotę wiary).

Pismo Święte wyraźnie zobowiązuje rodziców do świadomego kształtowania dzieci, np.: „aby to, co zlecił naszym ojcom, podawali swym synom,

15 M. Wolicki, Psychologiczne uwarunkowania przekazu wartości w rodzinie, w: Międzypokoleniowy przekaz wartości w rodzinie, red. J. Zamorski, Stalowa Wola-Rzeszów 2009, s. 12.

16 M. Wolicki, Psychologiczne uwarunkowania przekazu wartości w rodzinie, dz. cyt., s. 15.

17 J. Savage, Mama - najlepszy zawód na świecie, Warszawa 2007, s. 41. 
aby to poznało przyszłe pokolenie, synowie, co się narodzą, że mają pokładać nadzieję w Bogu i nie zapominać dzieł Boga, lecz strzec Jego poleceń" (Ps 78,5b-7); „Niech pozostaną w twym sercu te słowa, które ja ci dziś nakazuję. Wpoisz je twoim synom, będziesz o nich mówił przebywając w domu, w czasie podróży, kładąc się spać i wstając ze snu" (Pwt 6,6-7). Warto zwrócić uwagę na użyte w wersecie Pwt 6,7 słowo „wpoić”: „Zauważmy, że o niczym innym Bóg nie powiedział «wpoisz» - jak tylko o przekazie Bożych norm. Nie powiedział tutaj «przekaż wiarę», "naucz wiary» - to są jeszcze stany odwracalne. Wpajanie zaś oznacza wpasowanie czegoś jednego w coś drugiego tak, żeby to w nim zostało trwale i nierozłącznie"18. Kluczowe jest wykorzystanie wszelkich możliwości, a technika - drugorzędna: rodzic ma wpajać Boże treści nieustannie, przez przebywanie z dzieckiem, od przebudzenia do zaśnięcia, w domu i w podróży.

Najcenniejszy historyczny przykład spisanego programu wychowawczego pochodzi z XVII wieku. W roku 1640, kiedy Jan Sobieski, przyszły król Polski, miał niecałe jedenaście lat, został razem ze swoim starszym bratem Markiem wysłany do Krakowa na naukę. Ojciec ich, Jakub Sobieski sporządził szczegółowy dokument dotyczący tego, czego miał pilnować ich mentor. Instrukcja ta pokazuje intencjonalny model wychowania oraz rozpisuje go na kilkanaście konkretnych obszarów. Punkt pierwszy - Nabożeństwo - dotyczył rozwoju duchowego. Instrukcja zobowiązywała obu młodzieńców do codziennego udziału we mszy św., którą mieli zaczynać dzień, do codziennej modlitwy, a Marka do regularnego dziękowania Bogu za wcześniejsze cudowne uratowanie go od śmierci ${ }^{19}$. W niedziele i święta mieli się więcej modlić oraz szukać dobrych kazań: „y chodzić tam, gdzie by przednieysi kaznodzieie byli" ${ }^{20}$. Wyraźnie widać, że relacja z Bogiem była najważniejszym punktem i fundamentem tego XVII-wiecznego modelu

\footnotetext{
18 M. J. Wołochowicz, Rodzicielska formacja sumień, w: W trosce o życie i zdrowie człowieka, red. U. Dudziak, Lublin 2015, s. 255.

19 Instrukcyja JmćPana Jakuba Sobieskiego, wojewody bełskiego, starosty krasnostawskiego, dana JmćPanu Orchowskiemu, iako Dyrektorowi Jmć Pana Marka, Jana Sobieskich, Woiewodziców Bełskich, gdy ich na studia do Krakowa oddał, przez punkta pisana, w: Pisma do wieku i spraw Jana Sobieskiego, t. 1, cz. 1, Obejmująca pisma od roku 1629 do roku 1671, zebrał i wydał F. Kluczycki, Nakł. Akademii Umiejętności Krakowskiej, Kraków 1880, s. 12-13 (Acta Historica Res Gestas Poloniae Illustrantia, II).

20 Instrukcyja JmćPana Jakuba Sobieskiego..., dz. cyt., s. 13.
} 
wychowania. Opisany historyczny program z XVII wieku może być i dzisiaj doskonałą inspiracją do kształtowania młodego pokolenia.

\section{Koncepcja wychowania do wiary "Wierzące Dzieci” (Mariola i Piotr Wołochowicz, 2014-2018)}

Koncepcja wychowania do wiary „Wierzące Dzieci” powstała jako efekt wieloletniej pracy i refleksji Marioli i Piotra Wołochowiczów oraz ich ponaddwudziestoletniego doświadczenia w pracy w ramach Misji Służby Rodzinie. Opis tej koncepcji został przez nich zawarty w czterech publikacjach książkowych: Wierzace dzieci. O tym, jak wychować dzieci do dojrzałej wia$r y^{21}$; Wierzace dzieci reanimacja. O tym jak odbudować $w$ dzieciach żywa wiarę ${ }^{22}$; Wierzace dzieci 3. Ugruntowanie i rozwój. O tym, jak tworzyć dobre środowisko przekazu wiary ${ }^{23}$; Skad się biora wierzace dzieci? Jak skutecznie przekazać wiare swoim dzieciom ${ }^{24}$.

Osią tej koncepcji jest zaproponowanie listy sześciu czynników, które mają realny wpływ na wiarę dzieci, i uczulenie rodziców, by zwrócili szczególną uwagę na te dziedziny, wraz z podsunięciem im szeregu kreatywnych pomysłów. Lista sześciu czynników została po raz pierwszy opublikowana w książce Wierzące dzieci, a potem szerzej opisana w Skąd się biorą wierzace dzieci?. Oto najważniejsze myśli tam zawarte:

- Modlitwa za dzieci. Istotą ma być gorliwe indywidualne przedstawianie dzieci Bogu w modlitwie systematycznej i zaplanowanej - a nie tylko okazjonalnie. To niejako „wylewanie serca” przed Bogiem a nie tylko odmawianie modlitw w intencji. Modlitwa powinna być konkretna oraz ukierunkowana głównie na rozwój relacji dziecka z Bogiem.

\footnotetext{
21 M. i P. Wołochowiczowie, Wierzące dzieci. O tym, jak wychowywać dzieci do dojrzałej wiary, Kraków 2014.

22 M. i P. Wołochowiczowie, Wierzące dzieci reanimacja. O tym, jak odbudować w dzieciach żywą wiarę, Kraków 2015.

23 P. Wołochowicz, Wierzace dzieci 3. Ugruntowanie i rozwój. O tym, jak tworzyć dobre środowisko przekazu wiary, Kraków 2018.

24 M. i P. Wołochowiczowie, Skąd się biorą wierzące dzieci. Jak skutecznie przekazać wiare swoim dzieciom, Kraków 2018.
} 
- Autentyczność życia chrześcijańskiego w rodzinie. Każda sytuacja życiowa powinna być widziana, przeżywana i komentowana w kontekście wiary. Życie mają przepełniać wdzięczność dla Boga i dla ludzi oraz radykalne posłuszeństwo Bogu i pełna zgodność tego, co się mówi, z tym, jak się żyje. Bardzo ważne jest praktyczne zachowywanie przez rodziców trzech najważniejszych priorytetów: (1) Bóg; (2) współmałżonek; (3) dzieci.

- Wieczorne czytanie dzieciom. Jest to oryginalny wynalazek rodziny Wołochowiczów, stosowany „od zawsze”, aby dobrze wykorzystać czas zasypiania dzieci lekturą (i wspólnym komentowaniem) wartościowych książek niosących chrześcijańskie przesłanie. Dzięki temu dzieci zasypiają napełnione Bożymi treściami - i to one pracują $\mathrm{w}$ nich w nocy (a nie np. oglądany wieczorem serial telewizyjny). Patrząc wstecz, widać, że wspaniałych owoców tego czytania nie sposób przecenić.

- Życie atrakcyjne i radosne. Nie chodzi jednak o dawanie dzieciom bez końca nowych gadżetów i zapewnianie atrakcji. Rzecz w tym, aby nie tylko czuły poczucia, że jako chrześcijanie coś tracą (np. nie mogą robić pewnych rzeczy, akceptowanych w innych rodzinach), ale żeby miały świadomość, że to właśnie z Jezusem życie jest bardziej atrakcyjne i pełne wspaniałych treści - że dostają więcej niż ich rówieśnicy. Oczywiście wymaga to twórczego zaangażowania i wysiłku rodziców!

- Umacnianie i wzrost. To przede wszystkim pilotowanie osobistej relacji dziecka z Bogiem. Najpierw regularne czytanie mu Biblii dla dzieci, potem stopniowe wprowadzanie w samodzielną lekturę Pisma Świętego połączoną z modlitwą (np. w formie oazowego Namiotu Spotkania). Trzeba także zapewnić towarzystwo innych wierzących dzieci. Niezwykle ważne jest czuwanie nad dzieckiem, zauważanie jego problemów życiowych i pomoc w trudnych sytuacjach poprze pokazywanie Bożych rozwiązań. Czynnikiem spinającym będzie żywa i gorliwa modlitwa rodzinna ${ }^{25}$.

- Przebywanie z dziećmi. Należy obalić mit jakoby ,jakość” czasu spędzanego z dziećmi zastępowała jego ilość. Potrzebne są obie rzeczy.

25 Zob. M. i P. Wołochowicz, Bojowy szyk rodzinny nie tylko ku przetrwaniu, czyli... nasza modlitwa rodzinna, „Domowy Kościół” (2010) nr (117), s. 35-38. 
Dlatego w wychowaniu kluczowa jest ciągła obecność mamy i nieoddawanie dzieci do placówek opiekuńczych, potem zaś poświęcanie starszym dzieciom czasu i troski.

\section{Znaczenie obecności w domu pełnoetatowej mamy}

Dla Misji Służby Rodzinie - od momentu jej powstania w 1992 roku aż do dziś - jednym z najważniejszych tematów jest rola mamy pozostającej z małymi dziećmi w domu. Współczesne polskie kobiety trzeba jednoznacznie zachęcić, aby jako mamy małych dzieci zostawały z nimi w domu, zamiast oddawać je do przedszkoli (o żłobkach już nie mówiąc). Stąd wezwanie: „Mamo, zostań ze mną w domu - to najlepsze dla mego rozwoju”.

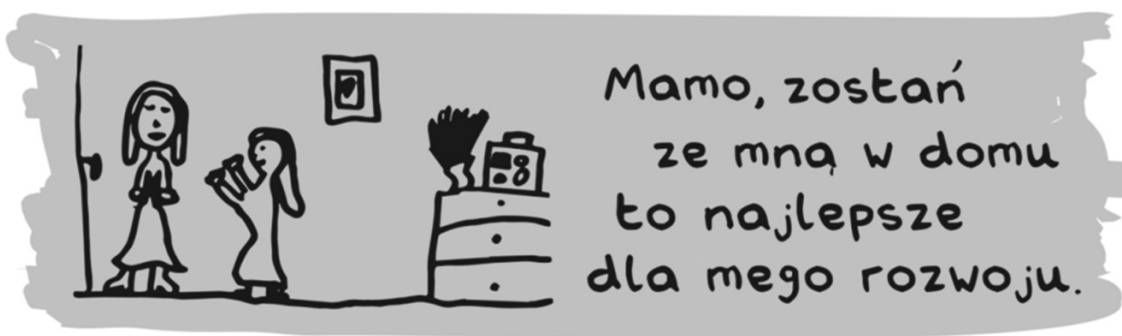

„Klub Twórczych Mam” - inicjatywa ksztattowania stabilnych osobowości rodziców i dzieci.

Źródło: Materiały własne Fundacji Misja Służby Rodzinie.

Rodzice często nie mają świadomości, iż wczesne oddawanie dziecka do placówek wychowawczych niesie za sobą szereg negatywnych konsekwencji:

- Inni ludzie mają na nie zbyt duży wpływ i to oni kształtują je zamiast rodziców.

- Zabiera się dziecku ostatnie lata beztroskiego dzieciństwa.

- Zabiera się czas, jaki mogłoby spędzić w domu i po prostu być razem $\mathrm{z}$ rodzicem.

- Naraża się je na częstsze choroby, bo w przedszkolu łatwiej o zarażenie się. 
- Zwiększają się koszty prowadzenia domu - dodatkowo płaci się za przedszkole, za dojazdy matki do pracy, za nowe stroje, buty, kosmetyki, częściej kupowane lekarstwa itp.; jest też mniej czasu na oszczędne gospodarowanie finansami.

- Matka, która prowadzi dom i nie rezygnuje z kariery zawodowej, tak naprawdę pracuje na dwa etaty, biorąc na siebie brzemię ponad siły, i nie jest już w stanie dobrze zatroszczyć się o dziecko.

W szczególnym niebezpieczeństwie jest kształtujący się dopiero system wartości dziecka - może się okazać, że: „nasze dzieci wyznają nie nasze ideały, lecz system wartości swoich wychowawców"26. Natomiast młody człowiek wychowywany w domu poniekąd automatycznie uczy się tego, czym żyją rodzice, i przejmuje ich wartości. Następnie zaś w przyszłości, po założeniu własnej rodziny, samo będzie funkcjonować w podobny sposób.

Współczesna cywilizacja niestety wywiera na kobiety olbrzymią presję, aby poświęciły one własne dzieci na rzecz „kariery zawodowej”27. Można powiedzieć, że pasują tu słowa proroka Micheasza: „Kobiety ludu mego wyrzucacie $\mathrm{z}$ ich miłych domów; dzieciom ich odbieracie chwałę moją na zawsze" (Mi 2,9). Potrzebne jest więc działanie na rzecz uświadamiania matkom małych dzieci, jak ważne jest ich bycie w domu i uchronienie dzieci przed placówkami wychowawczymi ${ }^{28}$. Przesłanie to równolegle powinno dotrzeć także do ojców.

Główna nagroda za taką inwestycję w dzieci przychodzi po dwudziestu latach, gdy stają się one dojrzałymi, dorosłymi, godnymi zaufania ludźmi zdolnymi do założenia trwałej rodziny. Spełniają się wówczas słowa z Księgi Syracha: „Skończył życie jego ojciec, ale jakby nie umarł, gdyż podobnego sobie zostawił" (Syr 30,4).

26 K. Mills, Mamusiu, gdzie jesteś?, dz. cyt., s. 38.

27 Zob. M. i P. Wołochowicz, Nie składajmy dzieci na ofiarę, „Cel” (2006) nr 1 (4), s. $20-21.32$.

28 Szerokie omówienie tematu zob. M. i P. Wołochowiczowie, Skąd się biorą wierzące dzieci?, dz. cyt., s. 129-179. 


\section{Wychowanie do miłości i czystości}

Najważniejsze w wychowaniu jest, by rodzice pociągnęli dzieci do wartości przez swoją pasję, autentyczność, dając im udział w czymś wspaniałym, a nie popychali przed sobą, narzucając określony styl życia. Gdy dziecko widzi, że rodzice sami z radością żyją tym, czego wymagają, będzie bardziej skłonne przyjmować tę wartość w naturalny sposób.

Obszar dobrego wychowania do miłości i czystości jest szczególnie wrażliwy: wymaga, aby rodzice sami żyli w pełnej czystości obyczajowej, aby dom był wolny nie tylko od wszelkiego rodzaju pornografii, ale też od nieczystego mówienia o sprawach seksualności. Młody człowiek powinien poznać i zrozumieć klasyczny podział rodzajów miłości (w tym różnicę między zakochaniem a dojrzałą miłością). Na bazie tego w świetle rodzajów miłości można przeanalizować typowe powody za współżyciem przed ślubem i przeciw niemu. Ponadto bardzo ważne jest obalenie mitów: o „wyrażaniu miłości” oraz o „sprawdzeniu dopasowania”. Wreszcie potrzebne jest szerokie uświadomienie poważnych konsekwencji przedwczesnej inicjacji seksualnej.

Oryginalnym dorobkiem małżeństwa Wołochowiczów jest opracowanie autorskiego modelu i lekcji PDŻ na temat relacji chłopak-dziewczyna oraz przeprowadzenie takich zajęć z młodzieżą ${ }^{29}$. Autorzy stworzyli także tabelę przedstawiającą typowe „za” i „przeciw” w kwestii współżycia przedmałżeńskiego oraz opracowali ich analizę. Najczęściej podawane:

$Z A \rightarrow$ ciekawość; przyjemność; sprawdzenie dopasowania; nabranie doświadczenia; wyrażanie miłości; rozładowanie napięcia; zaimponowanie innym; żądanie „dowodu miłości”;

PRZECIW $\rightarrow$ nieplanowane poczęcie dziecka; ryzyko chorób wenerycznych; groźba AIDS; nierozmienianie się „na drobne”; niepoznawanie się w innych sferach; zachowanie panowania nad sobą; złe wspomnienia w przyszłości; utrata reputacji; zachowanie czystości dla przyszłego współmałżonka.

Podczas analizy powodów „przeciw” obok uświadomienia olbrzymich zagrożeń współżycia przedmałżeńskiego warto też wskazać powody

29 Zob. M. Wołochowicz, Dlaczego nam o tym nikt nie mówił?! (migawki z naszej pracy $z$ młodzieża), „Wychowawca” (1995) nr 11, s. 17-18. Istnieje też nagranie spotkania dla Duszpasterstwa Akademickiego na KUL w roku 2003: M. i P. Wołochowicz, Pole minowe ludzkiej seksualności, CD-audio, Warszawa 2019 oraz video - od 30 min. filmu z VI Forum Młodzi i Miłość: www.youtube.com/watch?v=j1NY-afKcrc (08.06.2020). 
pozytywne zachowania czystości. W gruncie rzeczy odpowiada to przesłaniu z Pierwszego Listu św. Jana: „Nie miłujcie świata ani tego, co jest na świecie! Jeśli kto miłuje świat, nie ma w nim miłości Ojca. Wszystko bowiem, co jest na świecie, a więc: pożądliwość ciała, pożądliwość oczu i pycha tego życia nie pochodzi od Ojca, lecz od świata. Świat zaś przemija, a z nim jego pożądliwość; kto zaś wypełnia wolę Bożą, ten trwa na wieki” (1 J 2,15-17).

Bardzo ważne jest też pokazanie młodemu człowiekowi, że dla wszechobecnego modelu randkowania istnieje znacznie lepsza alternatywa - zapomniane współcześnie zaloty. Niezobowiązujące randkowanie z kolejnymi osobami lub ciągłe odraczanie ślubu nie prowadzą do stabilnych życiowych rozwiązań, ale ku „mentalności rozwodowej” i przykrym konsekwencjom (od poczucia odrzucenia poprzez złe wspomnienia, utratę poczucia wartości, wiary w istnienie prawdziwej miłości, utratę dziewictwa aż po nieplanowane poczęcie dziecka). W zalotach natomiast punktem wyjścia jest pragnienie obdarowania miłością drugiej osoby i danie jej szczęścia. Są one zobowiązującą ofertą, ukierunkowaną na całe przyszłe życie i mającą oparcie w realnych możliwościach, zamiast tzw. „bujania w obłokach”. Zaloty respektują wolność drugiego i nie wywierają na nim presji. Oznaczają zabieganie o względy drugiej osoby, troskę o relację, a nie dążenie do własnej przyjemności, typowe dla randkowania.

Paul Jehle w książce Dating vs. Courtship dokonuje analizy zjawiska randkowania, pokazuje słabości tego modelu oraz proponuje alternatywę w postaci budowy środowiska młodzieżowego reprezentującego te same wartości, a potem promowanie zalotów jako drogi do wyboru współmałżonka. Autor wymienia i obala m.in. następujące mity dotyczące randek: 1. „Jedną z największych potrzeb w moim życiu jest chodzenie z drugą sobą, bo to pomoże mi pokonać samotność i zaspokoi moje potrzeby społeczne"30. Tymczasem w pokonaniu odczuwanej samotności człowiekowi pomaga relacja z Bogiem oraz środowisko kościelne, a nie randkowanie ${ }^{31}$; 2. „Konieczną częścią dorastania jest posiadanie kogoś, z kim możesz dzielić swoje uczucia i zaufanie. Randkowanie zapewnia tego typu spełnienie" ${ }^{\text {"32 }}$. W rzeczywistości dominujące w randkowaniu emocje uniemożliwiają prawdziwe dzielenie

30 P. Jehle, Dating vs. Courtship. A Vision for the Generation Who Will Build a New Foundation of Truth, Love \& Purity, ed. 3, Plymouth 1996, s. 16" (tu i dalej tłum. P. Wołochowicz).

\footnotetext{
31 P. Jehle, Dating vs. Courtship, dz. cyt., s. 16.

32 P. Jehle, Dating vs. Courtship, dz. cyt., s. 16.
} 
się w zaufaniu ${ }^{33}$. Jehle zauważa: „Prawdopodobnie największym błędem w tych poglądach jest założenie, iż za to, cokolwiek robimy teraz, nie zapłacimy ceny w przyszłości” ${ }^{34}$.

Niezwykle interesujące treści związane z wychowaniem do życia w rodzinie przedstawia wydana na początku XX wieku książka Antoniny Smiškovej Przy kądzieli. Pogadanki dla kobiet o ważnych sprawach ${ }^{35}$. Zasadniczo publikacja skierowana jest do dziewcząt, zawiera jednak także życiowe wskazówki dla młodych mężczyzn. Prowadzi odbiorców poprzez konkretne dziedziny życia, m.in.: edukację, wybór współmałżonka, obowiązki małżonków i rodziców, pomoc dla rodzącej, relację do rodziców i teściów, wychowanie dzieci, kształtowanie dziewcząt, naukę szkolną dzieci, relacje macocha-pasierbica, gospodyni-służba aż do ukazania przykładów kobiet, które brały na siebie odpowiedzialność za dom w szczególnie trudnych okolicznościach. Czytając kolejne rozdziały, współczesny czytelnik może być zaskoczony, jak wiele mądrości życiowej i aksjologicznej jest w nich zawarte.

Wiele przedstawionych analiz i wskazówek pozostaje aktualne dla współczesnego pokolenia, np.: „Tymczasem przed każdym pieniężnym interesem, kupnem, sprzedażą, objęciem służby zastanawiamy się więcej niż przed ślubem"36. Dzisiaj byśmy to ujęli jako ostrzeżenie przed ślubem z zakochania zamiast z miłości. Autorka ostrzega dziewczyny przed niewłaściwą motywacją zawierania małżeństwa - z lęku przed staropanieństwem: „Nieraz, obawiając się, że temu odmówi, a inny po nią nie przyjdzie, bierze pierwszego z brzegu, i wtedy najgorzej wychodzi; bo stokroć lepiej przez całe życie brnąć samej, niż mieć kulę u nogi, która ściąga w błoto lub pcha do rowu”37. $\mathrm{W}$ istocie, we współczesnej Polsce można zaobserwować, że coraz więcej kobiet po trzydziestym roku życia od dawna pragnie założyć rodzinę, ale jest im bardzo trudno znaleźć dobrego kandydata na męża ${ }^{38}$.

Smišková podsuwa także kryteria wyboru żony czy męża oparte właśnie na wartościach. Do mężczyzn pisze: „Gdy masz się żenić, młodzieńcze, nie

\footnotetext{
33 P. Jehle, Dating vs. Courtship, dz. cyt., s. 16-17.

34 P. Jehle, Dating vs. Courtship, dz. cyt., s. 20.

35 Antoszka [A. Smišková], Przy kądzieli. Pogadanki dla kobiet o ważnych sprawach, wyd. 2, Warszawa 1913, s. 7.

36 Antoszka [A. Smišková], Przy kądzieli, dz. cyt., s. 7.

37 Antoszka [A. Smišková], Przy kądzieli, dz. cyt., s. 10.

38 Temat ten szeroko omawia Magdalena Wołochowicz w: Chwilowo panna. Żyjacc pełnią życia z nadzieja na dalszy ciąg, Kraków 2017.
} 
szukaj w kobiecie pieniędzy, ani gruntu, ani piękności, lecz głównie dobroci charakteru, szlachetności duszy i rozumu. Majątek - to rzecz nabyta, dobra żona - to klejnot nieoszacowany”39. Do kobiet zaś: „Przede wszystkim nie powinna zważać jedynie na majątek i gospodarkę, lecz na serce i umysł człowieka. Tylko ten, kto jest dobrym synem, bratem, sąsiadem, może być dobrym mężem" ${ }^{40}$.

\section{Współczesna literatura dla młodzieży}

Pomocą w kwestii wychowania do życia w rodzinie jest przeznaczona dla szkół średnich książka Zanim wybierzesz... Prowadzi ona młodego człowieka w wieku od piętnastu do dziewiętnastu lat przez obszary samoakceptacji, komunikacji, przyjaźni, miłości, zrozumienia własnego ciała, wyzwań okresu przedmałżeńskiego, chodzenia ze sobą, narzeczeństwa, jedności małżeńskiej, przekazywania życia, planowania rodziny, wychowania dzieci, kariery zawodowej. Wydana w roku 1993 stanowiła pierwszą kompleksową propozycję podręcznika przygotowania do życia w rodzinie po roku 1987.

Autorzy prowadzą dialog z czytelnikiem, wyposażając go w konieczne informacje, opisując zależności, zadając pytania i uświadamiając konsekwencje konkretnych wyborów. Całość apeluje do młodego czytelnika w odniesieniu do ważnych decyzji życiowych: „Zanim wybierzesz - najpierw zbadaj rzeczywistość, rozważ różne możliwości oraz ich konsekwencje, a dopiero potem podejmij dobrą decyzję". Do książki dołączony jest też Program do przedmiotu wychowanie do życia $w$ rodzinie, który także może być pomocą nie tylko dla nauczycieli, ale także dla samych rodziców ${ }^{41}$.

Spośród bardzo licznych popularnych publikacji dla młodzieży poruszających temat relacji chłopak-dziewczyna, stojących na fundamencie klasycznych wartości, obok Zanim wybierzesz... na szczególne polecenie zasługują inne tytuły autorstwa Marioli i Piotra Wołochowiczów ${ }^{42}$ : seria trzech książek o relacjach „Prawdziwa miłość": I nie zmarnować życia. O zaakceptowaniu

\footnotetext{
39 Antoszka [A. Smišková], Przy kądzieli, dz. cyt., s. 8.

40 Antoszka [A. Smišková], Przy kądzieli, dz. cyt., s. 13.

41 Omówienie książki i programu w: „Wychowawca” (1997) nr 5, s. 26-27.

42 Pełne dane tych pozycji podane są w bibliografii.
} 
siebie, rozwoju i przygotowaniu do życia w rodzinie, Którędy do malżeństwa. Kogo poślubić i czy warto czekać z seksem do ślubu?, Miłość niejedno ma imię. O zakochaniu, randkowaniu i rozpoznawaniu prawdziwego uczucia. Ponadto książki o płciowości i płodności dla młodszej i starszej młodzieży: Mariola Wołochowicz, Porozmawiaj ze mną. Jak rozmawiać ze swoim dzieckiem o seksualności, Mariola, Piotr Wołochowiczowie, Skąd się biorą dzieci?, a także klasyka dla młodzieży - Walter Trobisch, Pokochać siebie, Miłości trzeba się uczyć, Kochałem dziewczynę, Małżeństwo na nowo odkryte oraz Kristen Clark, Bethany Baird, Boska kobieta w cudownym planie Stwórcy - książka, która celnie demaskuje modernistyczną wizję kobiecości.

\section{Postulaty skierowane do rodziców}

Obecne czasy wymagają także szczególnej motywacji rodziców ku podjęciu zadania wychowania dzieci do życia w rodzinie. Przede wszystkim należy im przekazać, że:

- skuteczne wychowanie w ogóle oraz do życia w rodzinie jest możliwe;

- w żadnym wypadku nie powinni oni obniżać poprzeczki swoim pociechom;

- model życia o wysokich wymaganiach należy oprzeć o proces internalizacji wartości.

Wierzący rodzice mogą dostarczyć dzieciom źródła mocy do sprostania tym wyzwaniom: osobistej relacji z Bogiem przez Jezusa i życia w mocy Ducha Świętego. Dziś wielu rodziców potrzebuje motywacji, aby w ogóle podjąć poważną walkę o swoje dzieci. Inspiracją może być przykład biblijny - słowa Dawida kierowane do Goliata, szydzącego z Izraelitów od czterdziestu dni: „Ty idziesz na mnie z mieczem, dzidą i zakrzywionym nożem, ja zaś idę na ciebie w imię Pana Zastępów, Boga wojsk izraelskich, którym urągałeś. (...) Ponieważ jest to wojna Pana, On więc wyda was w nasze ręce" (1 Sm 17,45-47). Wychowanie dzieci jest zadaniem danym rodzicom przez Boga. Gdy współczesny „Goliat” seksualizacji i wszelkich stojących za nią ideologii próbuje zagarnąć dzieci, walka rodziców to „wojna Pana”, bo sam Bóg za nimi staje. 


\section{Bibliografia}

Antoszka [A. Smišková], Przy kądzieli. Pogadanki dla kobiet o ważnych sprawach, wyd. 2, Warszawa 1913.

Benedykt XVI, List do diecezji rzymskiej o pilnej potrzebie wychowania (21.01.2008), „L'Osservatore Romano” wyd. pol. (2008) nr 4 (302), s. $4-6$.

Clark K., Baird B, Boska kobieta w cudownym planie Stwórcy, tłum. M. Wołochowicz, Częstochowa 2019.

Grabowscy M. i W., Niemyscy A. i M., Wołochowiczowie M. i P., Zanim wybierzesz... Program do przedmiotu wychowanie do $\dot{z} y$ cia $w$ rodzinie, Warszawa 1999.

Grabowscy M. i W., Niemyscy A. i M., Wołochowiczowie M. i P., Zanim wybierzesz... Przygotowanie do życia $w$ rodzinie. Podstawy wychowania seksualnego, wyd. 2, Warszawa 1999.

Instrukcyja JmćPana Jakuba Sobieskiego, wojewody bełskiego, starosty krasnostawskiego, dana JmćPanu Orchowskiemu, iako Dyrektorowi Jmć Pana Marka, Jana Sobieskich, Woiewodziców Bełskich, gdy ich na studia do Krakowa oddat, przez punkta pisana, w: Pisma do wieku i spraw Jana Sobieskiego, t. 1, cz. 1, Obejmująca pisma od roku 1629 do roku 1671, zebrał i wydał F. Kluczycki, Nakł. Akademii Umiejętności Krakowskiej, Kraków 1880, s. 10-29 (Acta Historica Res Gestas Poloniae Illustrantia, II).

Jehle P., Dating vs. Courtship. A Vision for the Generation Who Will Build a New Foundation of Truth, Love \& Purity, ed. 3, Plymouth 1996.

Mills K., Mamusiu, gdzie jesteś? Czyli: o trudnych wyborach współczesnej kobiety, Warszawa 1994.

Savage J., Mama - najlepszy zawód na świecie, Warszawa 2007.

Trobisch W., Kochałem dziewczynę, tłum. I. Doleżał-Nowicka, Częstochowa 2006.

Trobisch W., Małżeństwo na nowo odkryte. Partnerstwo jako klucz do odnowy rodziny, wyd. 4 uzup., Częstochowa 2017.

Trobisch W., Miłości trzeba się uczyć, wyd. 14 popr., Częstochowa 2016.

Trobisch W., Pokochać siebie, tłum. R. Malinowski CPPS, wyd. 18 popr., Częstochowa 2017. 
Wolicki M., Psychologiczne uwarunkowania przekazu wartości w rodzinie, w: Międzypokoleniowy przekaz wartości w rodzinie, red. J. Zamorski, Stalowa Wola-Rzeszów 2009, s. 9-19.

Wołochowicz M. i P., Bojowy szyk rodzinny nie tylko ku przetrwaniu, czyli... nasza modlitwa rodzinna, „Domowy Kościół” (2010) nr (117), s. 35-38.

Wołochowicz M., Chwilowo panna. Żyjąc petnia życia z nadzieją na dalszy ciąg, Kraków 2017.

Wołochowicz M., Dlaczego nam o tym nikt nie mówił? (migawki z naszej pracy $z$ młodzieża), „Wychowawca” (1995) nr 11 (35), s. 17-18.

Wołochowiczowie M. i P., I nie zmarnować życia. O zaakceptowaniu siebie, rozwoju i przygotowaniu do życia $w$ rodzinie, wyd. 2 popr. i rozsz., Warszawa 2017.

Wołochowiczowie M. i P., Którędy do małżenstwa. Kogo poślubić i czy warto czekać z seksem do ślubu?, wyd. 2 popr., Warszawa 2017.

Wołochowiczowie M. i P., Miłość niejedno ma imię. O zakochaniu, randkowaniu $i$ rozpoznawaniu prawdziwego uczucia, wyd. 2 popr., Warszawa 2017.

Wołochowicz M. i P., Nie składajmy dzieci na ofiare, „Cel” (2006) nr 1 (4), s. 20-21.32.

Wołochowicz M. i P., Pole minowe ludzkiej seksualności, CD-audio, Warszawa 2019.

Wołochowicz M., Porozmawiaj ze mną. Rozmowy z dziećmi o seksualności, Kraków 2010.

Wołochowicz M. i P., Przekaz pokoleń, „Cel” (2006) nr 3 (6), s. 30-31.46.

Wołochowicz M. J., Rodzicielska formacja sumień, w: W trosce o życie i zdrowie człowieka, red. U. Dudziak, Lublin 2015, s. 249-261.

Wołochowiczowie M. i P., Skąd się biorq dzieci? Poznaj wspaniały Boży plan na ludzka płodność, wyd. 2 przejrzane i poszerzone, Częstochowa 2019.

Wołochowiczowie M. i P., Skąd się biora wierzace dzieci? Jak skutecznie przekazać wiarę swoim dzieciom, Kraków 2018.

Wołochowiczowie M. i P., Wierzace dzieci. O tym, jak wychowywać dzieci do dojrzałej wiary, Kraków 2014.

Wołochowiczowie M. i P., Wierzace dzieci reanimacja. O tym, jak odbudować $w$ dzieciach żywa wiarę, Kraków 2015.

Wołochowicz P., Wierzace dzieci 3. Ugruntowanie i rozwój. O tym, jak tworzyć dobre środowisko przekazu wiary, Kraków 2018. 
Wunsch A., Die Verwöhnungsfalle. Für eine Erziehung zu mehr Eigenverantwortlichkeit, München 2013.

Wunsch A., Abschied von der Spaßpädagogik. Für einen Kurswechsel in der Erziehung, München 2003.

Zarzycka B., Rozwój własny a życie oddane Ewangelii, „Pastores. Kwartalnik Poświęcony Formacji Kapłańskiej" (2010) nr 3 (48), s. 27-35.

VI Forum Młodzi i Miłość, www.youtube.com/watch?v=j1NY-afKcrc (08.06.2020). 
